Ad van Liempt

\title{
HET ZELFBEELD VAN HET JOURNAAL
}

Het JOU R NAAL bestaat vijftig jaar en in die tijd is er een stortvloed van meningen over het programma gepubliceerd. Van beroepscritici vooral - het JOU RNAAL is vanaf de eerste dag intensief gevolgd door generaties televisierecensenten. En van het publiek: het JOU RNAAL is altijd ruim bedeeld in de ingezonden brievenrubrieken. Iedereen heeft een mening over het JO U R NAAL. Maar wat denkt het JO U R NAAL van zichzelf? Wat valt er te zeggen van het zelfbeeld van deze organisatie, die in vijftig jaar uitgroeide van vijf tot meer dan tweehonderd personeelsleden?

Dat is nog niet zo gemakkelijk te zeggen. Want wat is eigenlijk een zelfbeeld? 'Het voorgestelde zelf dat men denkt te zijn,' zegt Van Dale - met een niet alledaagse, licht poëtische plechtstatigheid. Het zwakke van deze definitie zit in het woord 'men', dat niet voor niets tot de lafste en lelijkste woorden van onze taal behoort. Want wie is die 'men' bij het JournAAL? De hoofdredacteur? De spraakmakende minderheid van de redacteuren die op interne vergaderingen het hoogste woord heeft? Of de zwijgende meerderheid, van wie we maar zelden iets horen waar een zelfbeeld uit te destilleren valt?

Toch is het een interessante vraag, al staat tevoren vast dat een eenduidig antwoord niet te geven zal zijn. En al staat ook vast dat het antwoord door de jaren heen sterk verschilt. Want onderzoek naar de ontwikkeling van het nieuwsprogramma van de publieke omroep leert dat er sprake is van sterke golfbewegingen, die door allerlei factoren worden bepaald. Belangrijk daarin is de mate van onafhankelijkheid die het JO U R NAAL voor zichzelf kan bevechten, vooral op de omroepen die het JOURNAAL enkele decennia met succes proberen klein en onbeduidend te houden. Belangrijk is ook de journalistieke omgeving, die na I989 ingrijpend veranderde met de komst van commerciële televisie. En verder is van groot belang de persoon van de hoofdredacteur, die bij nadere beschouwing een zeer sterke invloed op het imago blijkt te hebben, extern zowel als intern, en dus ook wel op 'het voorgestelde zelf' dat het JOU R NAAL denkt te zijn. Vandaar dat de geschiedenis van het JOURNAAL zich logisch laat opdelen in hoofdredactionele regimes - dat zijn er tot nu toe zeven: Carel Enkelaar, Dick Simons, Ed van Westerloo, Peter Brusse, Gerard van der Wulp, Nico Haasbroek en Hans Laroes. ${ }^{\mathrm{I}}$ 
Toen op 5 januari I956 het eerste NTS-JOU R NAAL de lucht inging, stond Carel Enkelaar aan het hoofd van een organisatie van vijf personen, secretaresse Renny Pereira meegerekend. Het Jo u R NAAL zond maar drie keer per week uit, op de dagen dat er televisie was: op dinsdag, donderdag en zaterdag. En dat NTS-JO U RNAAL kon bekeken worden op nog geen 50.000 (al dan niet geregistreerde) televisieapparaten, meer waren er toen niet. De journalistieke betekenis van het programma was alleen daarom al te verwaarlozen. Maar dat veranderde snel. De groei van het aantal toestellen is spectaculair: in vijf jaar tijd werden het er een miljoen. Kijkcijfermetingen waren er destijds nog niet maar de Nederlandse Stichting voor Statistiek hield in I958 een enquête onder een steekproef uit de ruim 300.000 tv-bezitters van destijds. ${ }^{2}$ Daaruit bleek dat elke journaaluitzending door circa 66 procent werd bekeken. Het is niet gedurfd om daaruit de conclusie te trekken dat het nieuwsprogramma een belangrijke trekker was, en dus een factor van betekenis in de groei van het aantal toestellen.

Met Carel Enkelaar had de NTs een zelfbewuste hoofdredacteur in huis. Hij mocht graag krantenjournalisten ontvangen (voormalige collega's - hij kwam zelf van de Volkskrant), die hij dan imponeerde met veel internationale telefoongesprekken en sterke staaltjes logistiek. En ook de eerste reporter van het NTS-JOURNAAL, Coen van Hoewijk, straalde wel enig zelfvertrouwen uit. Hij werd vrij snel een bekende persoonlijkheid, onder andere omdat het tot zijn specialisme behoorde om internationale beroemdheden, die Nederland aandeden, op Schiphol op te vangen en voor het JOURnAAL te interviewen. Josephine Baker, Harry Truman, Eleanor Roosevelt, Jayne Mansfield, Marlene Dietrich, David Ben Goerion, Louis Armstrong - het is maar een bescheiden bloemlezing uit het plakboek van Van Hoewijk. De inmiddels 82-jarige journalist geeft toe dat er 'geen grammetje nieuws' in die gesprekken zat, maar dat ze 'heel goed waren voor het imago van het Jou RNAAL. '3 Ze pasten daarmee uitstekend in de ambitie van hoofdredacteur Enkelaar die zich meer dan gemiddeld bekommerde om de public relations van zijn programma. Peter de Ruyter, die vanaf i96o de redactie kwam versterken, herinnert zich dat Enkelaar voortdurend telexen naar kranten zat te sturen om aandacht te vragen voor bijzonder nieuws en bijzondere beelden die het JOU RNAAL zou gaan brengen: hij was bij vlagen meer PR-agent dan hoofdredacteur. De eerste zorg van het NTS-JOURNAAL was concurrent Polygoon de loef af te steken. Dat makkte een tot dan toe erg populair weekjournaal voor de bioscopen, en het journaal wilde deze concurrent wegblazen. Daar was geen andere reden voor dan de ambitie van de hoofdredacteur, die op zijn medewerkers oversloeg: Enkelaar genoot van competitie, en vooral van winnen. Dat is hem gelukt. Volgens Van Hoewijk vooral door de inzet van verslaggevers. Polygoon kende die niet, daar maakten cameramensen de opnamen, die later, na de montage, van tekst werden voorzien. Het NTS-JOU RNAAL ontdekte al snel dat het beter was een verslaggever mee te sturen met de camera- 
Redactievergadering in 1956 met aan het bureau hoofdredacteur Carel Enkelaar; verder zijn herkenbaar Pier Tania en Roel Renssen. Bron: NOS-JOURNAAL/ Beeld en Geluid, Hilversum

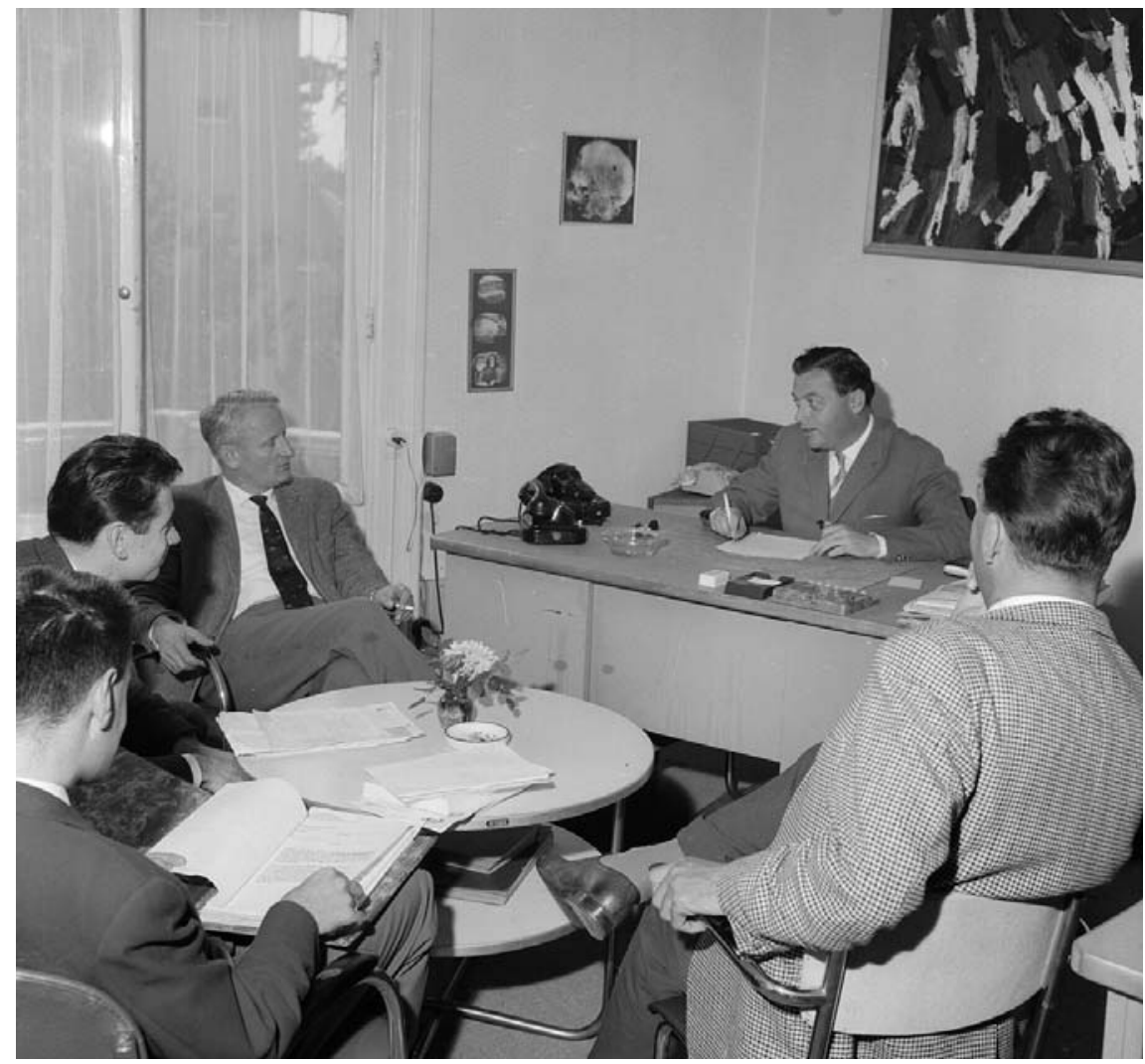

man en op die manier de nieuwsgaring op de lokatie te intensiveren. De eerste keer was eind januari I956. Van Hoewijk werd naar Schiphol gestuurd waar twee Nederlandse militairen terugkeerden uit Jakarta. Ze hadden getuigd in het geruchtmakende proces-Jungschlaeger, een tegen Nederland gericht politiek proces in onze voormalige kolonie Indonesië. De reporter herinnert het zich bijna vijftig jaar later nog heel goed. Van Hoewijk: 'Ik vroeg: hoe moeten we dat doen? Enkelaar zei: "Dat weet ik ook niet, zie zelf maar.” Ik heb de ene man links van mij gezet, en de andere rechts, en ik heb eerst de ene vragen gesteld en daarna de andere, en daarmee was de zaak gepiept.' Zo kwam misschien wel het eerste nieuwsinterview uit onze geschiedenis tot stand.

Het aftroeven van Polygoon en de niet aflatende stroom positieve recensies in de dagbladen ('weer een van die krachttoeren die dit journaal met de vaart van een meteoor doet rijzen aan de vaderlandse TV-hemel,' juichte Het Vrije Volk) hebben zonder enige twijfel geleid tot een positief zelfbeeld bij de medewerkers van het JOU RNAAL. Ze glommen zelfs van trots toen op I3 september I96I aan het nTS-JO U R NAAl de Prins Bernhard Televisieprijs werd toegekend, de belangrijkste onderscheiding van de branche. Het juryrapport was lovend, op het larmoyante af, het JOU R NAAL vervulde zijn functie voorbeeldig. En die functie was 
niet mis: 'Haar eigenlijke opdracht: schakel te zijn tussen mens en wereld. Haar eigenlijke functie: de wereld zichtbaar en begrijpelijk te maken. ${ }^{4}$ Daar kwamen nog allerlei buitengewoon juichend getoonzette interviews overheen; na vijf jaar was dat piepkleine experiment uitgegroeid tot een zeer geslaagde onderneming.

\section{$1963-1974$}

Maar achter de schermen broeide er al van alles binnen dat succesvolle Jou RNAAL. Er waren problemen over de salariëring. Er ontstond een conflict naar aanleiding van de eerste omroepstaking (eind I96I) waaraan de redacteuren wel deelnamen en de hoofdredacteur niet. Programmacommissaris Jan Willem Rengelink vond dat Enkelaar te wild, te onbesuisd was en wilde graag wat meer bezonkenheid en wat meer diepgang in het jo u R NAAL implanteren. Voor Enkelaar was eind I9 62 het nieuwe eraf, hij stapte over naar het bedrijfsleven waar hij overigens geheel niet kon aarden. Het Jo U R NAAL kreeg in NCRV-employee Dick Simons begin 1963 een nieuwe hoofdredacteur. Hij was het tegendeel van Enkelaar: formeel, afwachtend, afstandelijk en met een zwak ontwikkeld gevoel voor nieuws en voor public relations.

Simons is uiteindelijk de langst zittende hoofdredacteur: hij vertrekt pas in mei 1974 en is daarmee meer dan elf jaar verantwoordelijk geweest voor het NTS-journaAl. Zijn periode wordt wel omschreven als de 'dark age' van het journaal. Het journaal verloor zijn positieve imago in de andere media en werd langzamerhand het debiele neefje van de Nederlandse journalistiek. Een belangrijk deel van de oorzaak hiervan is terug te voeren op de structuur van het omroepbestel. Het JOU RNAAL viel onder het NTs-bestuur dat gevormd werd door vertegenwoordigers van de omroepen. Onder Enkelaar was dat ook al zo, sterker nog, toen was de feitelijke verantwoordelijkheid in handen gelegd van een zogeheten 'journaalcommissie', die bestond uit actualiteitenchefs van de omroepzuilen. Aan hen was Enkelaar verantwoording verschuldigd, maar Enkelaar trok zich daar weinig of niets van aan. Hij was de vrijbuiter die de journaalcommissie links en rechts passeerde en zijn eigen weg ging. Toen Simons kwam was die commissie opgeheven, maar de greep van de omroepen op het JO U RNAAL werd juist steviger. In de tweewekelijkse vergaderingen van de Werkgroep Actualiteiten werd voortdurend kritiek uitgeoefend op de berichtgeving van het JourNAAL. De onderwerpen waren te lang, er werden teveel achtergronden belicht, en werden mensen in het nieuws geïnterviewd - en de omroepen vonden dat het JOU RNAAL daarmee op hun terrein kwam. Hoofdredacteur Simons was daar gevoelig voor. Menigeen zag hem als zetbaas van de omroepen. In werkelijkheid streefde hij naar een vreedzame coëxistentie met de omroepen, wat erop neer kwam dat het journaAl bij dreigende conflicten diende in te binden. En die conflicten dreigden steeds vaker, want de actualiteitenrubrieken, met ACHTER HET NIEUWS van de VARA En BRANDPUNT van de KRO voorop, waren in op- 
komst. De omroepen investeerden in hun journalistieke afdelingen, trokken talentvolle journalisten aan en hielden die scherp en enthousiast met ruime (reis)budgetten. Ze mochten ieder een paar keer per jaar gedurende een paar weken naar een brandhaard ergens in de wereld en dat leverde tal van vaak aangrijpende reportages op. Lastige concurrentie van het JOURNAAL konden ze daarbij niet gebruiken. In I964 pleitten de chefs van de actualiteitenrubrieken ervoor dat het JOURNAAL zich, net als op de radio, voortaan strikt tot korte nieuwsberichten zou beperken, flitsen van hooguit veertig seconden. Reportages zouden moeten worden verboden, afgeschaft. ${ }^{5}$ De leiding van de NTs wees dat van de hand, ook Simons stelde zich ertegen teweer. Daarna kwam KRovoorzitter Harry van Doorn met het voorstel dat onderwerpen in het JOU RNAAL voortaan nooit meer langer zouden mogen zijn dan zestig seconden. Op die manier bleef er voor de omroepen alle gelegenheid om achtergronden te brengen. ${ }^{6}$ Ook daartegen heeft Simons zich verzet.

Dit soort stringente regels is er nooit gekomen, maar toch hebben de acties van de omroepen gewerkt. Het jo u R NAAL werd voorzichtiger, banger. Dat leidde er in maart I966 toe dat de journaalredactie zichzelf in opspraak bracht, door eigen terughoudendheid. Cineast Louis van Gasteren bood de redactie beelden aan van een incident in Amsterdam, waar vier agenten een burger zonder zichtbare reden in elkaar hadden geslagen. De hoofdstedelijke politie was in die dagen in overspannen toestand door provo-acties en de rellen rond het huwelijk van Beatrix en Claus, ruim een week eerder. Het jo u R NAAL weigerde de beelden en Van Gasteren ging ermee naar ACHTER H ET N I EUws dat ze's avonds in aanzienlijke lengte uitzond. Een paar dagen later moest hoofdredacteur Simons zich openlijk verontschuldigen voor deze blunder. Hij was zelf niet te bereiken geweest, zei hij. Hij heeft natuurlijk niet als reden aangevoerd dat zijn medewerkers inmiddels totaal geïndoctrineerd waren met terughoudendheid. 'Bij twijfel niet inhalen', was het devies volgens de dienstdoende eindredacteur.?

Zulke incidenten zijn natuurlijk niet bevorderlijk voor het zelfbeeld van een redactie. Het jo u R NAAL zat in de hoek waar de klappen vielen en het zelfvertrouwen kromp snel ineen. Het Parool deed in die dagen verslag van een congres over de journalistiek (met Dick Simons als een van de aanwezigen - daarom was hij op de dag van Van Gasterens film onbereikbaar), waarin Laurens ten Cate, een van de hoofdredacteuren van de Leeuwarder Courant, flink uithaalde. Hij noemde het JOURNAAL een zwak programma: te weinig geschoolde journalisten bij de staf, een zekere starheid in de onderwerpenkeuze, een nogal serviele houding tegenover autoriteiten, lieve filmpjes over lieve, vrijblijvende gebeurtenissen, en weinig initiatief om zelf dingen uit te zoeken. ${ }^{8}$ Kortom, alle reden voor journaalmedewerkers om zich slechts met een zak over het hoofd in het publiek te vertonen.

Toch is dat maar een deel van de werkelijkheid. Want Dick Simons heeft enige tijd na zijn aantreden wel ingezet op meer binnenlandse berichtgeving. Hij heeft daartoe een nieuwsdienst opgezet, waarvoor hij Joop Marmelstein als 
chef heeft aangetrokken. Die was afkomstig van United Press, had een reputatie van bekwaam organisator en hij straalde onmiskenbaar gezag uit. De nieuwe chef had een sterke voorkeur voor alles wat een uniform aan had en vanaf dat moment steeg het aantal wachtmeesters, kolonels, adelborsten en kapiteins in de journaals tot opmerkelijke hoogte. Marmelstein had het vertrouwen van de hoofdredacteur en kreeg dan ook alle ruimte om de cameraploegen van het JO U RNAAL daarheen te dirigeren waar verkeersongelukken waren gebeurd, schoorstenen werden opgeblazen, leidingen door de zeebodem werden getrokken of papierfabrieken in lichterlaaie stonden. Overal werden politiefrequenties afgeluisterd en het JOU RNAAL kreeg zelfs een radiokamer zodat voortdurend contact kon worden gelegd met bedreigde gebieden. Het was de opkomst van de 'zwaailichtjournalistiek' en degenen die zich daarmee bezighielden vertoonden al snel een zonnig zelfbeeld. Een van de nieuwsdienstredacteuren herinnerde zich later wat hij bij binnenkomst van zijn chef als advies meekreeg: 'Laat nooit merken dat je niets te doen hebt. Desnoods ga je een paar keer door de gangen lopen met een dikke map papieren onder je arm. De nieuwsdienst heeft het altijd druk.'

Daar begonnen de verschillende zelfbeelden bij het J O U R NAAL al flink uiteen te lopen. Marmelstein vond dat het Jo U R NAAL er goed aan deed de opkomst van een beweging als provo te negeren - en ook andere protestbewegingen kwamen er bij hem niet in. Maar andere journaalredacteuren schaamden zich voor dit gebrek aan journalistiek gewicht en hadden dus een erg negatief beeld over de berichtgeving. Zo herinnert parlementair verslaggever Jaap van der Ploeg zich heel goed dat het JO U R NAAL alleen maar Haags nieuws bracht als het absoluut zeker was. Speculaties, bijvoorbeeld over ministersposten tijdens de formatie, waren uit den boze: het journaal bracht louter feiten, achtergronden moest het aan de omroepen overlaten. Van der Ploeg: 'Alle kranten stonden tijdens de kabinetsformaties vol met nieuws, maar wij brachten dan niks. Het was niet officieel, het kon nog veranderen, dus deden wij niks. Heel frustrerend. ${ }^{\text {,o }}$ En Henk Lichtenveldt, die euforisch was teruggekeerd na een dramatisch verslag over de bezetting van de Enka-fabriek, kreeg van zijn hoofdredacteur te horen dat hij, door geëmotioneerde mensen in beeld te brengen, 'de privacy van die mensen ernstig had geschaad. ${ }^{\text {,II }}$ Simons wilde dat niet. Zodra er nieuwe, onbekende ontwikkelingen op het JOURNAAL afkwamen zei de hoofdredacteur dat 'we dat maar aan de omroepen moeten overlaten. Dat ligt niet op onze weg.'

Sommige ex-medewerkers spreken er nu met schaamte over. De roerige jaren zestig zijn geheel aan het JOU R NAAL voorbij gegaan, de status van het programma was in de ogen van de opinieleiders van destijds bijzonder laag. Maar er waren ook factoren waar het JOU RNAAL weer van opkikkerde: de Nederlandse televisiekijker raakte in die tijd ernstig verslaafd aan het jo U R NAAL en begon het als zijn belangrijkste nieuwsbron te beschouwen. Tussen I964 en I97I bedroeg het aantal kijkers naar het achtuurjournaal tussen de 3,5 en 4 miljoen, in I974 was het zelfs opgelopen naar 5 miljoen (het achtuurjournaal werd toen parallel op twee netten uitgezonden). ${ }^{\text {I2 }}$ Goed, de kijkers hadden geen alternatief ter 
beschikking, maar ze namen toch massaal kennis van de berichtgeving van de NTs, vanaf I969 nos, die overigens voor het overgrote deel uit het buitenland afkomstig was. Sinds I958 was de uitwisseling van nieuwsbeelden via de Eurovisie steeds belangrijker geworden. Daardoor kwam een constante stroom beelden op gang, langzamerhand vanuit de hele wereld. Die Eurovisie (een Nederlands initiatief, van Enkelaar en Rengelink) werd de aorta van het JOU RNAAL. Het snel verwerken van grote gebeurtenissen uit de hele wereld begon steeds meer een specialisme van het JOU R NAAL te worden, waaraan de redactie, ook in minder goede tijden, enig zelfbewustzijn kon ontlenen. En zo was het zelfbeeld van het journaal ook in zijn 'dark age' gemengd.

Vanaf I970 begon de journaalredactie zich enigszins te roeren. Er kwam kritiek op hoofdredacteur Simons die ijlings wat soepeler en communicatiever werd. Er kwamen plenaire vergaderingen, er kwamen wat opstandiger types binnen en er kwam steeds meer discussie over de aard van de berichtgeving, over de aanpak van het nieuws uit het Midden Oosten en andere hete hangijzers. In I974 vertrok Simons, die vier jaar eerder al had laten doorschemeren dat hij niet al te lang meer wilde blijven. Na zijn vertrek eiste de redactie inspraak in zijn opvolging. De uit het bedrijfsleven naar de publieke omroep teruggekeerde Nos-directeur Carel Enkelaar (die Simons ongeschikt vond als hoofdredacteur en totaal niet met hem overweg kon) gaf de redactie enige ruimte en werkte samen met de redactie aan verruiming van de journaalmogelijkheden.

Binnen het bestuur van de Nos was inmiddels het inzicht gerijpt dat het Jo U RNAAL wat meer armslag zou moeten krijgen. Daarin speelde de nieuwe programmacommissaris Jan de Troye een belangrijke rol. Hij was ook afkomstig uit een van de oude zuilen (de VARA), maar realiseerde zich dat het publieke bestel gebaat was bij een sterk JO U RNAAL. Met de gerespecteerde VARA-voorzitter André Kloos als bondgenoot schiep hij de ruimte voor het JO U R NAAL om zich ook met achtergrondberichtgeving te mogen bezighouden. ${ }^{\mathrm{I}}$ Een door drie journaalredacteuren opgestelde 'Streefnota Journaal' haalde vrijwel ongeschonden de eindstreep. Daardoor ontstond er een aanzienlijk vrijer klimaat, waarin een nieuwe hoofdredacteur het journaal zou kunnen gaan uitbouwen. Dat de redactie in de benoeming voluit betrokken werd, kwam het zelfvertrouwen zeer ten goede (al blijkt nu pas dat de benoeming van de nieuwe hoofdredacteur in het geheim tóch was voorgekookt ${ }^{\mathrm{T}}$ ).

Die nieuwe man werd Ed van Westerloo, de eindredacteur van de KROrubriek BRANDPUNT. Hij ontpopte zich snel als het tegendeel van Simons, bemoeide zich dagelijks met de inhoud en werkte om te beginnen aan meer maatschappelijke relevantie in de nieuwskeuze. Hij nam spoedig afscheid van 


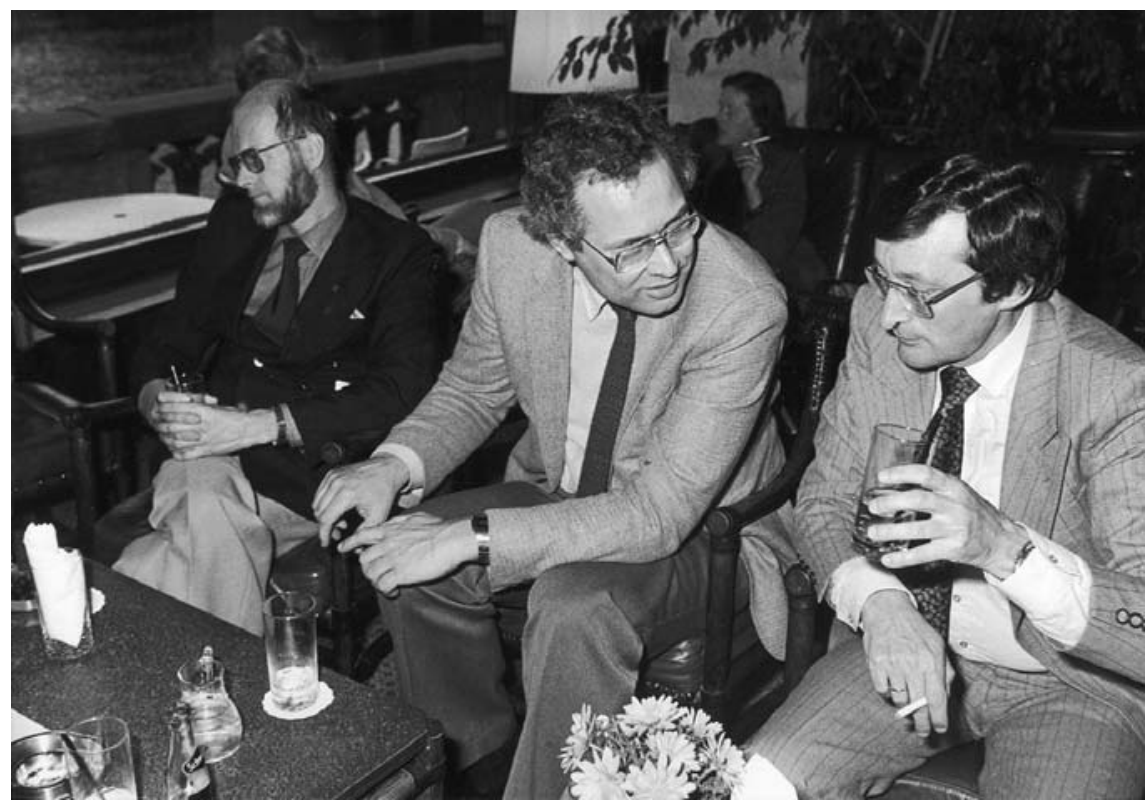

Hoofdredacteur Ed van Westerloo (rechts) in gesprek met zijn plaatsvervanger, Tom Kamlag. Bron: NOS-JOUNAAL / Beeld en Geluid, Hilversum

de zwaailichtjournalistiek en van de lichte onderwerpjes ('eerste lammetjes in de wei') waaraan zijn voorganger zo verknocht was geweest.

Van Westerloo gebruikte daarvoor het middel van management by speech - in toespraken en vooral in interviews benadrukte hij dat het JOU R NAAL serieuzer, maatschappelijker en daarmee zwaarder zou worden. Hij wilde ook journalistieke zwaargewichten als presentatoren en hij introduceerde de achtergrondberichtgeving. Om te beginnen over het buitenland, waarvoor hij eerst een commentator inzette (Henk Neuman, directeur van het Internationaal Instituut voor Vredesvraagstukken), en later een correspondentennet opzette. Vervolgens probeerde hij via de introductie van een binnenlandredactie ook daar het soortelijk gewicht van het JOU RNAAL te doen toenemen.

Met al die veranderingen (er zouden er in de jaren tachtig nog veel meer komen) gaf hij het Jou R NAAL weer aanzien en zelfvertrouwen. Van Westerloos adagium was dat het JO U R NAAL werd beoordeeld op dagen met groot en belangrijk nieuws. Hij inspireerde de redactie haar beste prestaties te leveren bij de Menten-affaire, de Lockheed-affaire en de treinkaping door een groep Molukkers bij De Punt in Drenthe. Heel Nederland zat dan aan het Jo u R NAAL gekluisterd en het programma was niet langer de risee van de journalistiek. 'De verslaggeving in alle extra journaaluitzendingen verliep de hele zaterdag vrijwel vlekkeloos,' schreef de Volkskrant over de dag dat de gijzeling van een trein bij De Punt en een school in Bovensmilde eindigde. 'Professioneel, journalistiek volwassen en heel begrijpelijk', vond het Algemeen Dagblad - dat waren kwalificaties die in elf jaar bewind van Dick Simons nooit waren voorgekomen. ${ }^{\text {I5 }}$ Dat was goed voor het zelfvertrouwen, en dus voor het zelfbeeld. En dat beeld werd alleen maar 
rooskleuriger toen Van Westerloo de gelegenheid kreeg het jOU RNAAL uit te bouwen. Hij mocht, na eindeloze strijd met de omroepen en de onderwijswereld, in I98I een JEU GDJOU RNAAL gaan beginnen. Er kwam in I9 83 een vast laat journaal bij, aanvankelijk om half elf. En eind I984 een nieuw vroeg journaal om half zes, met een afwijkend karakter: iedere dag dezelfde presentator (Maartje van Weegen), een vast format, een informele setting en veel meer liveelementen dan tot dan toe gebruikelijk. Dat JO U R NAAL werd een ongekend succes, al na een paar jaar zaten er 's middags om half zes tegen de twee miljoen mensen naar het journaal te kijken. Van Westerloo had, in samenwerking met Jan de Troye en Carel Enkelaar, de tegenstand van de omroepen omgezet in steun: de omroepen waren opeens erg blij met nieuwe journaals, omdat die veel extra reclame-inkomsten opbrachten, waarvan het overgrote deel door de omroepen mocht worden verdeeld.

Ed van Westerloo hield aan die successen volop zelfvertrouwen over. Als Amsterdammer toch al toegerust met een forse portie bluf, tobde hij maar zelden met 'het voorgestelde zelf dat men denkt te zijn' - zijn zelfbeeld. Onder zijn bewind heeft dat grotendeels ook wel voor het journaalpersoneel gegolden, al was aan het eind van zijn periode de magie wel uitgewerkt. De redactie begon de hoofdredacteur als een manager te zien, als een 'Macher' die zich niet te veel meer met de dagelijkse gang van zaken bemoeide. Toen Van Westerloo in I985 tot het hogere werd geroepen - hij volgde Enkelaar op als tv-directeur van de Nos - wilde de redactie een opvolger waar inspiratie van uitging, een journalist met frisse ideeën. Dat werd Peter Brusse, correspondent in Londen, die zonder twijfel aan die vereisten voldeed, maar geen enkele redactionele of managementervaring meebracht. Dat brak hem al heel snel op. Hij slaagde er niet in een aantal hoogst noodzakelijke veranderingen in de organisatie door te voeren en de gevolgen waren op korte termijn vrij ernstig: de redactie raakte verdeeld, de onderlinge sfeer werd slechter en al na twee jaar vertrok Brusse gedesillusioneerd naar Elsevier. Het Jou R NAAL was er beduusd van, het lag opeens weer onder vuur in de media en op de redactie ontbrak de sfeer van relatieve veiligheid die nodig is voor journalisten om te presteren.

\section{Vanaf eind jaren tachtig}

De redactie had van deze benoeming geleerd en wilde daarna direct een sterke organisator aan de leiding. Dat werd de chef van de Haagse redactie, Gerard van der Wulp. Hij voerde in een onnavolgbaar hoog tempo de hervormingen door waar Brusse zijn nek op had gebroken en herstelde de rust en de orde op de redactie. Intern en extern deed hij er alles aan om het geschonden vertrouwen in eigen kunnen bij het JOU RNAAL weer op peil te brengen. Zijn pogingen werden ruw verstoord door een geheel nieuwe ontwikkeling die zich in het voorjaar van I989 aandiende: een massale leegloop van de redactie. Eerst ging een aantal 
belangrijke redacteuren naar Nos LAAT, het nieuwe dagelijkse achtergrondprogramma dat de Nos mocht gaan produceren. En kort daarna volgde een exodus naar de twee commerciële stations die werden opgericht (TVIo en RTL Veronique) en die allebei ook een nieuwsprogramma zouden beginnen. Van der Wulp telde op enig moment 27 vacatures, en op zijn redactie heerste de ontreddering. ${ }^{16}$ Dat de zender TVIo uiteindelijk geen vergunning kreeg en alleen RTLNIEUWS als concurrent overbleef was niet meer dan een schrale troost. Het JOU RNAAL had zijn vacatures vervuld met een legertje onervaren krachten, dat in het najaar van I989 werd geconfronteerd met een van de nieuwsrijkste kwartalen van de twintigste eeuw: de val van het communisme in Oost-Europa. 'Het was niet allemaal even briljant,' zegt toenmalig redacteur Ed Ribbink met veel gevoel voor understatement. 'De uitzendingen wankelden,' herinnert toenmalig redacteur Gerri Eickhof zich. ${ }^{17}$ Achteraf zien velen de komst van zoveel jongeren bij het JOU RNAAL als een geschenk uit de hemel: er ontstond verjonging die anders nooit tot stand gekomen zou zijn, maar gemakkelijk ging het allemaal niet.

Reden tot zelfvertrouwen heeft het JOU RNAAL in die periode maar weinig gehad. Het zelfbeeld was tamelijk negatief en daar kwam een belangrijke factor bij: mediajournalisten begonnen te pas en te onpas het NOS-JOU RNAAL en RTLN I E UW met elkaar te vergelijken. In de meeste gevallen sloeg de balans door in het voordeel van RTL. De sympathie ging naar de nieuwkomer, de underdog, de Nos werd in de kranten gezien als een vette, volgevreten voormalige monopolist. Bij het NOS-JOURNAAL was er een oorlog voor nodig om weer enig gevoel van eigenwaarde terug te krijgen: de Golfoorlog in de eerste maanden van I99I. Toen bleek dat de Nederlandse kijker massaal naar de publieke omroep vluchtte. Dat verschijnsel zou zich de jaren daarop meermalen herhalen. Een sluitende verklaring is er nog niet voor gevonden, maar het is een onloochenbaar feit dat bij zeer groot, extreem nieuws de toevloed van kijkers naar de publieke omroep enorm is. ${ }^{\text {I8 }}$ Het JOU RNAAL weert zich dan over het algemeen heel goed, maakt honderden extra uitzendingen, ook's nachts, en blijkt in staat de enorme nieuwshonger bij het publiek te stillen. Directie en hoofdredactie schrijven in memo's dat ze trots zijn op het JO U RNAAL. Redacteur Maria Henneman herinnert zich:

'Het journaal kreeg er weer zelfvertrouwen door, ging weer meer uit van eigen kracht. "Kijk eens wat we gepresteerd hebben, het is ons gelukt." Er kwam weer trots, enorm belangrijk voor een organisatie, trots! Na de val van de Muur hadden we dat niet, dat ging houtje-touwtje, maar nu ging het heel soepel. Je merkte ook dat de mensen massaal naar de publieke omroep trokken. Dat is heel belangrijk voor ons.' ${ }^{\text {,9 }}$

Vanaf dat moment bleef het zelfbeeld van het JOU RNAAL enigszins fluctueren met de eigen prestaties. Het leefde wat op bij opmerkelijke prestaties (in I990 
trad minister Braks af na onthullingen door het JOU RNAAL over visfraude), en het zakte wat weg toen de kijkcijfers flink daalden omdat RTL met verstrooiende programma's een miljoen kijkers bij het achtuurjournaal weghaalde.

Pas in I997, toen Van der Wulp was opgevolgd door de veel avontuurlijker ingestelde Nico Haasbroek, werd het zelfbeeld van het journaal in zekere zin meetbaar gemaakt. Haasbroek legde ter oriëntatie de redactie een vragenformulier voor. ${ }^{20}$ Tachtig medewerkers vulden het in en gaven het JO U R NAAL gemiddeld een zeven. Ze vonden - aan de positieve kant - het JOU RNAAL gedegen en betrouwbaar, redelijk snel, en adequaat reagerend bij calamiteiten. Daar stond tegenover: te weinig eigen nieuws, te weinig verrassingen, te veel Haags nieuws, te saai, en teveel verschillende gezichten in beeld. Haasbroek nam zich voor daar wat aan te doen. Zijn optreden was nogal onconventioneel en viel daarom niet bij iedereen in goede aarde. Een aantal journaalredacteuren vond dat hij het JOU R NAAL lichter, luchtiger en daardoor onbeduidender wilde maken. De commerciële concurrentie - en dan vooral HART VAN NEDERLAN D van SBS - scoorde daarmee en dat maakte nogal wat journaalmedewerkers kopschuw. Bovendien had Haasbroek in het openbaar gepleit voor meer emotie in het nieuws - en ook dat werkte voor een deel van de redactie allesbehalve motiverend.

Opmerkelijk was dan ook het resultaat van een nieuwe enquête, in 2000 gehouden door de Journaalcommissie, het personeelvertegenwoordigend orgaan van het Jo U R NAAL. ${ }^{21}$ Ook daarin werd om een cijfer voor het JO U R NAAL gevraagd. Het gemiddelde was nu 6,7 - toch een aanzienlijke daling in drie jaar. De meest gehoorde opmerkingen betroffen angst voor 'opleuken' van het Jo U RNAAL en angst voor sensationelere berichtgeving. En verder waren veel redacteuren ontevreden over de organisatie, de communicatie en het personeelsbeleid. Maar de overheersende conclusie werd door een van de geënquêteerden simpel samengevat: 'Ondanks alle manco's is het werk verschrikkelijk leuk.'

In hun hart zijn ze het daar bijna allemaal ongetwijfeld mee eens, al die honderden journalisten die in de afgelopen vijftig jaar bij het Jou RNAAL hebben gewerkt. Dagelijks het nieuws volgen, selecteren, verslaan en bewerken voor een miljoenenpubliek - dat is heerlijk verslavend werk. De beoordeling van hun eigen kwaliteit wisselt sterk, en deint mee op de redactionele thermiek. Afhankelijk van sfeer, van de persoon van de hoofdredacteur, van de beoordeling door de media en van toevallige succesjes. Buitenstaanders ervaren het JOU RNAAL geregeld als arrogant. Verslaggevers hebben altijd haast, willen altijd voorrang, stampen door elke porseleinkast. Redacteuren eisen altijd volledige beschikbaarheid van gegevens en van personen, neigen tot oppervlakkigheid, eisen exclusiviteit.

Dat soort elementen zie je in het zelfbeeld nergens terug: daar zijn mensen van het NOS-JOU RNAAL zich totaal niet van bewust, dat zijn de observaties van derden. In een recent onderzoek van studenten naar het imago van het Jou RNAAL onder voorlichters van ruim zeventig voorlichtingsafdelingen van bedrij- 
ven en instellingen komt die klacht over arrogantie nog spaarzaam naar voren, maar dan vooral over het JOURNAAL van vroeger, het JOURNAAL van vóór de komst van de concurrentie. Tevredenheid overheerst bij de voorlichters, ze vinden in meerderheid het JOU RNAAL correct en professioneel. ${ }^{22}$

Het lijkt erop dat het Jou RNAAL zich na het vertrek van Nico Haasbroek enigszins heeft gestabiliseerd. Hoofdredacteur Hans Laroes hamert in e-mails aan zijn redactie geregeld op de noodzaak zelfbewust te zijn, van eigen kracht uit te gaan ('Wij zijn bijna vijftig jaar, wij kunnen wel wat'). Het zelfvertrouwen zal ongetwijfeld zijn bevorderd door de positie die de nieuwsvoorziening van de Nos heeft gekregen in de omroepplannen van staatssecretaris Van der Laan. Geen enkel instituut is er zo ongeschonden uitgekomen als het Nos-Nieuws. Het zijn de omroepen die voor hun toekomst moeten vrezen, de positie van het JOU R NAAL lijkt opeens onaantastbaar. Dat is het grote verschil met dertig, veertig jaar geleden. Het JournaAL heeft een brede politieke, maatschappelijke steun en bij groot nieuws trekt het nog altijd grote groepen Nederlanders aan. Het is in vijftig jaar de ruggengraat van de publieke omroep geworden.

I Deze indeling in periodes naar de zittingsduur van hoofdredacteuren heeft de auteur ook toegepast in zijn in november 2005 verschenen boek: Het Journaal, vijftig jaar achter de schermen van de televisiejournalistiek, Balans, Amsterdam 2005.

2 de Volkskrant, 21 juni I958.

3 Interview van de auteur met Coen van Hoewijk, 9 juli 2004.

4 Juryrapport Prins Bernhard Televisieprijs I96I, in: Archief-Enkelaar, doos 2, map 2, II in het Omroepmuseum, Beeld \& Geluid, Hilversum.

5 Memorandum van de Werkgroep Actualiteiten (waarin de chefs van de actualiteitenrubrieken waren verenigd) aan het College van Sectiehoofden, 29 januari I964, in: Centraal Archief nos, map 4.52I.I, Beeld \& Geluid, Hilversum.

6 Verslag vergadering Programmacommissie, I6 maart I964, in: Centraal Archief nos, map 4.52I.I, Beeld en Geluid, Hilversum.

7 De beschrijving van deze affaire is gebaseerd op gesprekken met enige betrokkenen, op een e-mail van G.J. van Lonkhuyzen aan de auteur (4 november 2004), op een interne productie van de School voor de Journalistiek in Utrecht, getiteld Bonje op de Buis, en op Nico Scheepmaker, Het meest bekeken programma. 25 jaar NOS-journaal. Naarden I98I.

8 Het Parool, 22 maart ig66.

9 Ontleend aan bijdrage van Gé van Berkel in: De jeugd van het journaal, interne publicatie ter gelegenheid van de reünie bij het 35-jarig bestaan van het Nos-Jou RNAAL in I99I.

IO Interview van de auteur met Jaap van der Ploeg, 22 november 2004.

II Interview Henk Lichtenveldt, 26 juni 2004.

I2 Cijfers verkregen van René van Dammen van de Dienst Kijk- en Luisteronderzoek van de Nos, in een e-mail aan de auteur, I8 augustus 2005.

I3 Afgeleid uit interview van de auteur met Jan de Troye, I8 januari 2005.

I4 Interview van de auteur met Ed van Westerloo, I5 november 2004. In dat gesprek legde Van Westerloo uit dat hij al maanden voor zijn benoeming in gesprek was met de leiding van de Nos. Toen er een afspraak was gemaakt dat hij voor het beheer met directeur Enkelaar en voor het beleid met programmacommissaris De Troye te maken zou hebben, begon de formele benoemingsprocedure, mét 'inspraak' van de redactie. 
I5 de Volkskrant respectievelijk Algemeen Dagblad, I3 juni 1977.

I6 Interview van de auteur met Gerard van der Wulp, I2 juli 2005.

I7 Interviews van de auteur met Ed Ribbink en Gerri Eickhof, I9 en I6 mei 2005.

I8 Wel blijkt uit allerlei onderzoeken van de Dienst Kijk- en Luister Onderzoek (кLO) van de Publieke Omroep dat kijkers het No S-jo u R NAAL hogelijk waarderen om zijn betrouwbaarheid. Volgens Gerard van der Wulp moet het Nos-jou R NAAL steeds 'een baken zijn in woelige tijden' (interview van auteur, I2 juli 2005).

I9 Interview van de auteur met Maria Henneman, 20 mei 2005.

20 Enquête onder journaalmedewerkers, verslag mei I997, in: Archief nos-JournaAl, map notities hoofdredactie, Beeld \& Geluid, Hilversum.

2I Verslag journaalcommissie over enquête onder medewerkers, Io augustus 2000, in: Archief nos-Jou RnAAL, map notities hoofdredactie, Beeld \& Geluid, Hilversum.

22 Rapport Instituut of instrument: het NOS-journaal anno 2005, van de faculteit der Historische en Kunstwetenschappen van de EUR, in het kader van het research seminar 'Beeldvorming en Media' (CH 44I7). 